Published in final edited form as:

Adv Exp Med Biol. 2017 ; 1006: 271-280. doi:10.1007/978-4-431-56550-5_15.

\title{
Role of drebrin at the immunological synapse
}

\author{
Vera Rocha-Perugini ${ }^{\# 1,2}$, Mónica Gordon-Alonso \#3, and Francisco Sánchez-Madrid ${ }^{1,2, \uparrow}$ \\ ${ }^{1}$ Servicio de Inmunología, Hospital de la Princesa, Instituto de Investigación Sanitaria La \\ Princesa, Madrid, Spain. Tel: 0034-915202307 \\ ${ }^{2}$ Vascular Pathophysiology Research Area, Centro Nacional de Investigaciones Cardiovasculares \\ Carlos III (CNIC), Madrid, Spain. Tel: 0034-914531200 \\ ${ }^{3}$ Institute de Duve, Universite Catholique de Louvain, Brussels, Belgium \\ \# These authors contributed equally to this work.
}

\begin{abstract}
Although drebrin was first described in neurons, it is also expressed in cells of the immune system, such as T lymphocytes and mast cells. Another member of the drebrin family of proteins, mammalian actin-binding protein 1 (mAbp-1) is more widely expressed and plays important roles in the function of macrophages, polymorphonuclear neutrophils, and B lymphocytes. We will briefly discuss on the function of mAbp-1 and drebrin in immune cells with emphasis on T cells. Specifically, drebrin enables the immune responses of $\mathrm{CD} 4^{+} \mathrm{T}$ lymphocytes. $\mathrm{T}$ cells are activated after the recognition of an antigen presented by antigen-presenting cells through cognate cell-cell contacts called immunological synapses (IS). In $\mathrm{CD} 4^{+} \mathrm{T}$ cells, drebrin associates with the chemokine receptor CXCR4, and both molecules redistribute to the IS displaying similar dynamics. Through its interaction with CXCR4 and the actin cytoskeleton, drebrin regulates $\mathrm{T}$ cell activation. $\mathrm{CD}^{+} \mathrm{T}$ cells are one of the main targets for the human immunodeficiency virus (HIV)-1. This virus utilizes the IS structure to be transmitted to uninfected cells, forming cell-cell contacts called virological synapses (VS). Interestingly, drebrin negatively regulates HIV-1 infection of $\mathrm{CD}^{+} \mathrm{T}$ lymphocytes, by regulating actin polymerization at the VS.
\end{abstract}

\section{Keywords}

drebrin; immune system; T lymphocytes; T cell activation; immunological synapse; CXCR4; HIV-1; virological synapse

\section{Introduction}

Drebrin was firstly described in neurons (Majoul et al. 2007; Sekino et al. 2007; Shirao and Obata 1985), however it was later revealed that it is also widely expressed in non-neuronal cells (Keon et al. 2000; Peitsch et al. 1999; Peitsch et al. 2001). In the immune system, drebrin is expressed in T lymphocytes and mast cells, but not in B lymphocytes. Drebrin

"Corresponding author: Francisco Sánchez-Madrid, Servicio de Inmunología, Hospital Universitario de la Princesa, C/ Diego de León 62, 28006 Madrid, Spain. Fax: 0034-915202374; Tel: 0034-915202307; fsmadrid@ salud.madrid.org. 
modulates T cell activation (Perez-Martinez et al. 2010), and histamine release and degranulation in mast cells (Law et al. 2015). However, whether drebrin plays any role in other immune cells remains to be determined. Mammalian Actin-binding protein 1 (mAbp-1), also called SH3P7, HPK1-interacting protein of $55 \mathrm{kDa}$ (HIP-55) or drebrin-like protein (DBL), is the other member of the drebrin family. mAbp-1, which is ubiquitously expressed (Kessels et al. 2000; Yamazaki et al. 2001), is also linked to leukocyte functions (Schymeinsky et al. 2011). In this chapter, we will describe in detail the roles of drebrin in the regulation of immune cells. We will also briefly address what is known about mAbp-1 in the immune system.

In mast cells drebrin modulates actin reorganization, regulating efficient FceRI-dependent degranulation and calcium influx (Law et al. 2015). Drebrin is also necessary for the actin reorganization associated with the activation of store-operated channels, thus modulating calcium entry in T cells (Mercer et al. 2010). The specific activation of store-operated calcium channels by drebrin will be further discussed in the following chapter (Chapter 7.1.2).

Macrophages engulf and digest foreign particles and dying cells, a process called phagocytosis. The activation of the central nervous system tissue-resident macrophages (microglia) results in reduced expression of drebrin in neuronal-glial co-cultures, suggesting an increased neuronal synaptic degeneration during inflammation (Jebelli et al. 2014). Drebrin expression in macrophages outside the nervous system has not been explored. However, in murine macrophages, the drebrin-like protein mAbp- 1 is expressed and interacts with Fyb (also termed SLAP-130 or ADAP), an immune cell specific protein involved in phagocytosis and macrophage activation (Yuan et al. 2005).

In primary murine neutrophils, mAbp- 1 is necessary for integrin aM $\beta 2-$ dependent bacterial phagocytosis (Schymeinsky et al. 2009). During an acute inflammatory response against bacterial and fungal pathogens, neutrophils are rapidly recruited to the inflammation site in a tightly controlled manner that involves rolling along the activated endothelium, neutrophil activation, firm adhesion, adhesion strengthening, spreading, intraluminal crawling and extravasation to the inflammation site (Mocsai 2013). $\beta 2$ integrins play an essential role in these steps of the extravasation process through tight modulation of its affinity (Evans et al. 2009). $\beta 2$ integrin activation triggers intracellular signalling cascades including the activation of the Syk kinase (Willeke et al. 2003), which is known to phosphorylate mAbp-1 in lymphocytes (Han et al. 2003; Larbolette et al. 1999). Upon $\beta 2$ mediated adhesion and migration of neutrophil-like differentiated HL-60 cells, mAbp-1 is enriched at the leading edge in a Syk-dependent manner, co-localizing with F-actin and hematopoietic progenitor kinase 1 (HPK1) (Hepper et al. 2012; Jakob et al. 2013). Moreover, mAbp- 1 controls neutrophil adhesion, spreading and intraluminal crawling in the in vivo inflamed cremaster muscle model and under physiological flow conditions in vitro, through the regulation of the transmission of mechanical forces from $\beta 2$ integrins to the actin cytoskeleton (Schymeinsky et al. 2009; Hepper et al. 2012).

B lymphocyte activation is triggered by antigen binding to B-cell receptors (BCR), leading to BCR signalling (Harwood and Batista 2010). After recognition of an antigen, BCR 
mediates subsequent antigen internalization and processing in specialized lysosomal compartments (Yuseff and Lennon-Dumenil 2015). Antigens are then presented at the B cell plasma membrane through the complexes formed with the major histocompatibility class II (MHC II), allowing cell-cell interaction with T lymphocytes (Yuseff and Lennon-Dumenil 2015). The drebrin-like protein mAbp-1 enables BCR-mediated antigen internalization, processing and presentation through the interaction with dynamin 2 and the actin cytoskeleton (Onabajo et al. 2008). In mouse B cells, mAbp-1 is phosphorylated by Src and Syk kinases after BCR stimulation (Larbolette et al. 1999). In those cells, mAbp-1 negatively regulates BCR signalling by recruiting inhibitory signaling proteins SHIP-1 and HPK1 to BCR clusters (Seeley-Fallen et al. 2014). Although drebrin expression has not been reported in B lymphocytes (Machtaler et al. 2014), it is aberrantly expressed in some leukaemias and lymphomas, e.g. Mantle cell lymphoma (Wang et al. 2010), B-cell precursor acute lymphoblastic leukaemia (BCP-ALL) (Vaskova et al. 2011), and in some immortalized cell lines, such as the B-cell precursor leukaemia BV113 and promyelocytic leukaemia HL-60, but not in acute myeloid leukaemia KG1a (Peitsch et al. 2001). ALL is a heterogeneous disease displaying a number of subtypes genetically different that differ in their capacity to respond to chemotherapy (Yeoh et al. 2002). Analyses of BCP-ALL by gene expression profiling reveal a correlation between high drebrin expression and the presence of the genetic lesion TEL/AML1 (chromosomal fusion 12p13-21q22) (Shurtleff et al. 1995), confirmed by RT-qPCR and flow cytometry (Vaskova et al. 2011). Analyses by gene expression profiling also show lower drebrin expression in patients who relapsed or failed to achieve complete clinical remission (Yeoh et al. 2002; Bhojwani et al. 2008).

\section{Drebrin at T cell Immunological Synapses}

In resting human $\mathrm{T}$ cells, drebrin co-localizes with F-actin along the cortical area beneath the plasma membrane (Perez-Martinez et al. 2010). Resting $\mathrm{CD}^{+}$and $\mathrm{CD}^{+}{ }^{+} \mathrm{T}$ lymphocytes are activated upon close contact with antigen presenting cells (APCs). These intercellular contacts are characterized by the formation of a highly organized molecular structure called the immunological synapse (IS) (Monks et al. 1998). IS formation requires the rearrangement of transmembrane and intracellular proteins into concentric rings, and constitutes an architectural requirement for the subsequent activation of T cells (Dustin et al. 2010). The IS structure displays a central ring, named central supramolecular activation cluster (cSMAC), surrounded by a peripheral ring (pSMAC), and an outer ring called distal supramolecular activation cluster (dSMAC). The actin cytoskeleton is involved in the segregation of molecules during IS formation and is needed for the maintenance of the IS (Ritter et al. 2013; Vicente-Manzanares and Sanchez-Madrid 2004). Actin polymerization is triggered by antigen engagement, allowing the $\mathrm{T}$ cell to project a lamellipodium that embraces the APC. When the contact is secured, polymerized actin gets cleared from the cSMAC (particularly in CD8 ${ }^{+}$cells) and accumulates at the pSMAC and dSMAC, where it functions mainly as a scaffold for the adhesion molecules. Many actin-related proteins, such as a $4 \beta 1$ integrin (VLA-4), talin, cofilin and Arp2/3, are enriched in the pSMAC and dSMAC (Eibert et al. 2004; Mittelbrunn et al. 2004; Nolz et al. 2007; Perez-Martinez et al. 2010; Rocha-Perugini et al. 2014a). During IS formation, drebrin is also recruited to these concentric areas and co-localizes with F-actin (Figure 1, left panel). Independently of its 
actin-binding domain, drebrin associates through its $\mathrm{N}$-terminal region with the chemokine receptor CXCR4 (Perez-Martinez et al. 2010). Chemokine receptors regulate cell migration by sensing the gradients of released chemokines (Rossi and Zlotnik 2000). CXCR4 signalling modulates T-cell adhesion proteins in response to chemokine CXCL12 (also called SDF-1a), and might also influence $\mathrm{T}$ cell activation as it has been found associated with the T cell receptor (TCR) (Kumar et al. 2006). We have shown that drebrin and CXCR4 are constitutively associated in $\mathrm{CD} 4^{+} \mathrm{T}$ cells and this association is enhanced by antigenic stimulation. Thus, during IS formation between superantigen-loaded B cells and CD4 ${ }^{+} \mathrm{T}$ cells, both drebrin and CXCR4 molecules redistribute to the pSMAC and dSMAC with identical dynamics (Figure 1, left panel). Drebrin association with CXCR4 is needed for CXCR4 redistribution to the IS, since knocking-down drebrin expression by siRNA impairs CXCR4 recruitment to the IS, without affecting CXCR4 expression levels (Perez-Martinez et al. 2010). Drebrin silencing in $\mathrm{CD}^{+}{ }^{+} \mathrm{T}$ cells impacts the IS formation, and consequently, $\mathrm{T}$ cell activation. Human $\mathrm{CD}^{+} \mathrm{T}$ cells silenced for drebrin conjugate normally with superantigen-loaded B cells and upregulate early activation markers such as CD69 (PerezMartinez et al. 2010). However, they show a decrease in F-actin polymerization at the IS and a reduced IL-2 production (mRNA) and secretion (Perez-Martinez et al. 2010). Therefore, drebrin enables the complete activation of the CD4 T cell.

Drebrin-related protein mAbp-1 is also expressed in human and murine T cells and is recruited to the IS during antigen presentation (Le Bras et al. 2004). Nevertheless, mAbp-1 does not affect F-actin polymerization or conjugate formation among antigen-loaded B cells and T cells. In fact, Le Bras and colleagues reported that mAbp-1 negatively regulates $\mathrm{T}$ cell activation by promoting TCR internalization and NFAT inhibition (Le Bras et al. 2004). Strikingly, in murine T cells the role of mAbp-1 seems completely different (Han et al. 2005). Although $T$ cell development is normal in mAbp-1 knock-out mice, $T$ cell activation through the TCR is decreased, showing reduced LAT/PLC $\gamma 1$ phosphorylation, and impaired HPK1 and JNK kinase activities (Han et al. 2005). Subsequently, T cell proliferation is reduced as well as IL-2 production, and the upregulation of activation markers such as CD69 (Han et al. 2005). Moreover, the authors could not detect any significant decrease in TCR internalization in these murine $\mathrm{T}$ cells upon stimulation with anti-CD3 antibodies. In rat $\mathrm{T}$ cells, mAbp-1 has been involved in the modulation of RhoA and the actin cytoskeleton (Skelton et al. 2010). Skelton and co-workers show that, in their system, the immunosuppressive activity that reduces $\mathrm{T}$ cell infiltration is due to reduced $\mathrm{T}$ cell motility and activation, which correlates with the dissociation of mAbp-1 from F-actin.

\section{Drebrin at Virological Synapses}

Transmission of human immunodeficiency virus (HIV)-1 can take place either by direct viral contact with target cells or through different types of cell-cell contacts with uninfected target cells, as filopodial bridges, tunnels, membrane nanotubes, and virological synapses (VS) (Permanyer et al. 2010; Zhong et al. 2013; Sagar 2014). VS are polarized cell-cell structures similar to IS, showing specific recruitment of receptors (CD4 and CXCR4) and adhesion molecules, and local actin polymerization (Haller and Fackler 2008; Piguet and Sattentau 2004). At any rate, HIV-1 entry into target cells depends on the interaction between the viral envelope glycoprotein complex gp120/gp41 (Env) and the cellular receptor CD4 and co- 
receptors CXCR4 and CCR5 (Blumenthal et al. 2012; Naif 2013; Dale et al. 2013; Agosto et al. 2015). In addition to transmembrane receptors, several host cytoskeletal proteins play a role throughout the viral replication cycle (Fackler and Krausslich 2006; Lehmann et al. 2011; Rocha-Perugini et al. 2014b). Among them, drebrin negatively regulates HIV-1 infection of $\mathrm{CD}^{+} \mathrm{T}$ lymphocytes (Gordon-Alonso et al. 2013). In agreement with its direct association with the HIV-1 co-receptor CXCR4 (Perez-Martinez et al. 2010), drebrin is specifically enriched at VS (Figure 1, right panel), and it co-localizes partly with the internalized virus at the cytoplasm of target $\mathrm{CD}^{+} \mathrm{T}$ lymphocytes (Gordon-Alonso et al. 2013). Using small interfering RNAs to knock-down drebrin expression, Gordon-Alonso and colleagues showed an increase in HIV-1 entry and Env-driven membrane fusion, while viral attachment and reverse transcription remained unaffected (Gordon-Alonso et al. 2013).

In order to enter its target cells, HIV-1 triggers a dynamic reorganization of the actin cytoskeleton (Permanyer et al. 2013; Rocha-Perugini et al. 2014b; Vorster et al. 2011; Yoder et al. 2008). Evidences suggest that actin polymerization is necessary for receptor clustering and stabilization, allowing viral-induced membrane fusion (Gordon-Alonso et al. 2013; Harmon et al. 2010; Kadiu et al. 2007; Komano et al. 2004). After the formation of the viral pore at the plasma membrane, local actin depolymerization is induced, probably because the highly polymerized actin structure presents a physical barrier to the entry of the viral core into the cell (Garcia-Exposito et al. 2013; Vasiliver-Shamis et al. 2009; Yoder et al. 2008). Drebrin silencing in $\mathrm{CD}^{+} \mathrm{T}$ lymphocytes impairs the accumulation of polymerized actin at VS (Gordon-Alonso et al. 2013). Interestingly, profilin recruitment towards VS was enhanced in drebrin knocked-down $\mathrm{CD}^{+}{ }^{+} \mathrm{T}$ cells (Gordon-Alonso et al. 2013), indicating that drebrin interaction with profilin is important in this process. Profilin enhances actin dynamics, and at high concentrations prevents actin polymerization (Bubb et al. 2003). Therefore, profilin increased accumulation at VS might account for the diminished levels of polymerized actin, as well as for the increased viral entry, observed in drebrin-silenced cells.

Using drebrin truncated forms, Gordon-Alonso and colleagues could determine which regions of the protein are involved in the regulation of HIV-1 infection. The overexpression of the drebrin truncated form Dreb(1-366)-GFP, which lacks the Prorich motives necessary for its interaction with profilin and other molecules, result in similar effects to the ones observed when silencing drebrin, while the overexpression of the truncated form Dreb(319-707)-GFP, which lacks the actin-binding domain, does not affect HIV-1 infection (Gordon-Alonso et al. 2013). Therefore, drebrin association to CXCR4 is essential for its negative role on HIV-1 infection, since Dreb(319-707)-GFP barely associates with the coreceptor (Perez-Martinez et al. 2010). Moreover, results obtained with Dreb(1-366)-GFP mutant confirm that drebrin negatively regulates HIV-1 infection by limiting profilin accumulation and by stabilizing polymerized actin at HIV-1 entry sites (Gordon-Alonso et al. 2013).

\section{Acknowledgements}

The authors thank Dr. M. Vicente-Manzanares (Hospital de la Princesa, Universidad Autónoma de Madrid, Spain) for the critical reading of the manuscript. This study was supported by grants: SAF2011-25834 and SAF2014-55579-R from the Spanish Ministry of Economy and Competitiveness, INDISNET-S2011/BMD-2332 from the Comunidad de Madrid, Cardiovascular Network RD12-0042-0056 from the Instituto Salud Carlos III, and 
ERC-2011-AdG 294340-GENTRIS. M. Gordon-Alonso was supported by Institute de Duve, Universite Catholique, Louvain.

\section{References}

Agosto LM, Uchil PD, Mothes W. HIV cell-to-cell transmission: effects on pathogenesis and antiretroviral therapy. Trends Microbiol. 2015; 23(5):289-295. DOI: 10.1016/j.tim.2015.02.003 [PubMed: 25766144]

Bhojwani D, Kang H, Menezes RX, Yang W, Sather H, Moskowitz NP, Min DJ, Potter JW, Harvey R, Hunger SP, Seibel N, et al. Gene expression signatures predictive of early response and outcome in high-risk childhood acute lymphoblastic leukemia: A Children's Oncology Group Study [corrected]. J Clin Oncol. 2008; 26(27):4376-4384. DOI: 10.1200/JCO.2007.14.4519 [PubMed: 18802149]

Blumenthal R, Durell S, Viard M. HIV entry and envelope glycoprotein-mediated fusion. J Biol Chem. 2012; 287(49):40841-40849. DOI: 10.1074/jbc.R112.406272 [PubMed: 23043104]

Bubb MR, Yarmola EG, Gibson BG, Southwick FS. Depolymerization of actin filaments by profilin. Effects of profilin on capping protein function Biol Chem. 2003; 278(27):24629-24635. DOI: 10.1074/jbc.M302796200

Dale BM, Alvarez RA, Chen BK. Mechanisms of enhanced HIV spread through T-cell virological synapses. Immunol Rev. 2013; 251(1):113-124. DOI: 10.1111/imr.12022 [PubMed: 23278744]

Dustin ML, Chakraborty AK, Shaw AS. Understanding the structure and function of the immunological synapse. Cold Spring Harb Perspect Biol. 2010; 2(10):a002311.doi: 10.1101/ cshperspect.a002311 [PubMed: 20843980]

Eibert SM, Lee KH, Pipkorn R, Sester U, Wabnitz GH, Giese T, Meuer SC, Samstag Y. Cofilin peptide homologs interfere with immunological synapse formation and T cell activation. Proc Natl Acad Sci U S A. 2004; 101(7):1957-1962. DOI: 10.1073/pnas.0308282100 [PubMed: 14762171]

Evans R, Patzak I, Svensson L, De Filippo K, Jones K, McDowall A, Hogg N. Integrins in immunity. J Cell Sci. 2009; 122(Pt 2):215-225. DOI: 10.1242/jcs.019117 [PubMed: 19118214]

Fackler OT, Krausslich HG. Interactions of human retroviruses with the host cell cytoskeleton. Curr Opin Microbiol. 2006; 9(4):409-415. DOI: 10.1016/j.mib.2006.06.010 [PubMed: 16820319]

Garcia-Exposito L, Ziglio S, Barroso-Gonzalez J, de Armas-Rillo L, Valera MS, Zipeto D, Machado JD, Valenzuela-Fernandez A. Gelsolin activity controls efficient early HIV-1 infection. Retrovirology. 2013; 10:39.doi: 10.1186/1742-4690-10-39 [PubMed: 23575248]

Gordon-Alonso M, Rocha-Perugini V, Alvarez S, Ursa A, Izquierdo-Useros N, Martinez-Picado J, Munoz-Fernandez MA, Sanchez-Madrid F. Actin-binding protein drebrin regulates HIV-1triggered actin polymerization and viral infection. J Biol Chem. 2013; doi: 10.1074/ jbc.M113.494906

Haller C, Fackler OT. HIV-1 at the immunological and T-lymphocytic virological synapse. Biol Chem. 2008; 389(10):1253-1260. DOI: 10.1515/BC.2008.143 [PubMed: 18713012]

Han J, Kori R, Shui JW, Chen YR, Yao Z, Tan TH. The SH3 domain-containing adaptor HIP-55 mediates c-Jun N-terminal kinase activation in T cell receptor signaling. J Biol Chem. 2003; 278(52):52195-52202. DOI: 10.1074/jbc.M305026200 [PubMed: 14557276]

Han J, Shui JW, Zhang X, Zheng B, Han S, Tan TH. HIP-55 is important for T-cell proliferation, cytokine production, and immune responses. Mol Cell Biol. 2005; 25(16):6869-6878. DOI: 10.1128/MCB.25.16.6869-6878.2005 [PubMed: 16055701]

Harmon B, Campbell N, Ratner L. Role of Abl kinase and the Wave2 signaling complex in HIV-1 entry at a post-hemifusion step. PLoS Pathog. 2010; 6(6):e1000956.doi: 10.1371/journal.ppat. 1000956 [PubMed: 20585556]

Harwood NE, Batista FD. Early events in B cell activation. Annu Rev Immunol. 2010; 28:185-210. DOI: 10.1146/annurev-immunol-030409-101216 [PubMed: 20192804]

Hepper I, Schymeinsky J, Weckbach LT, Jakob SM, Frommhold D, Sixt M, Laschinger M, Sperandio $\mathrm{M}$, Walzog B. The mammalian actin-binding protein 1 is critical for spreading and intraluminal crawling of neutrophils under flow conditions. J Immunol. 2012; 188(9):4590-4601. DOI: 10.4049/jimmunol.1100878 [PubMed: 22450813] 
Jakob SM, Pick R, Brechtefeld D, Nussbaum C, Kiefer F, Sperandio M, Walzog B. Hematopoietic progenitor kinase 1 (HPK1) is required for LFA-1-mediated neutrophil recruitment during the acute inflammatory response. Blood. 2013; 121(20):4184-4194. DOI: 10.1182/ blood-2012-08-451385 [PubMed: 23460610]

Jebelli J, Hooper C, Pocock JM. Microglial p53 activation is detrimental to neuronal synapses during activation-induced inflammation: Implications for neurodegeneration. Neurosci Lett. 2014; 583:92-97. DOI: 10.1016/j.neulet.2014.08.049 [PubMed: 25204787]

Kadiu I, Ricardo-Dukelow M, Ciborowski P, Gendelman HE. Cytoskeletal protein transformation in HIV-1-infected macrophage giant cells. J Immunol. 2007; 178(10):6404-6415. [PubMed: 17475870]

Keon BH, Jedrzejewski PT, Paul DL, Goodenough DA. Isoform specific expression of the neuronal Factin binding protein, drebrin, in specialized cells of stomach and kidney epithelia. J Cell Sci. 2000; 113(Pt 2):325-336. [PubMed: 10633083]

Kessels MM, Engqvist-Goldstein AE, Drubin DG. Association of mouse actin-binding protein 1 (mAbp1/SH3P7), an Src kinase target, with dynamic regions of the cortical actin cytoskeleton in response to Rac1 activation. Molecular biology of the cell. 2000; 11(1):393-412. [PubMed: 10637315]

Komano J, Miyauchi K, Matsuda Z, Yamamoto N. Inhibiting the Arp2/3 complex limits infection of both intracellular mature vaccinia virus and primate lentiviruses. Mol Biol Cell. 2004; 15(12): 5197-5207. DOI: 10.1091/mbc.E04-04-0279 [PubMed: 15385624]

Kumar A, Humphreys TD, Kremer KN, Bramati PS, Bradfield L, Edgar CE, Hedin KE. CXCR4 physically associates with the T cell receptor to signal in T cells. Immunity. 2006; 25(2):213-224. DOI: 10.1016/j.immuni.2006.06.015 [PubMed: 16919488]

Larbolette O, Wollscheid B, Schweikert J, Nielsen PJ, Wienands J. SH3P7 is a cytoskeleton adapter protein and is coupled to signal transduction from lymphocyte antigen receptors. Mol Cell Biol. 1999; 19(2):1539-1546. [PubMed: 9891087]

Law M, Lee Y, Morales JL, Ning G, Huang W, Pabon J, Kannan AK, Jeong AR, Wood A, Carter C, Mohinta S, et al. Cutting Edge: Drebrin-Regulated Actin Dynamics Regulate IgE-Dependent Mast Cell Activation and Allergic Responses. J Immunol. 2015; doi: 10.4049/jimmunol.1401442

Le Bras S, Foucault I, Foussat A, Brignone C, Acuto O, Deckert M. Recruitment of the actin-binding protein HIP-55 to the immunological synapse regulates $\mathrm{T}$ cell receptor signaling and endocytosis. $\mathrm{J}$ Biol Chem. 2004; 279(15):15550-15560. DOI: 10.1074/jbc.M312659200 [PubMed: 14729663]

Lehmann M, Nikolic DS, Piguet V. How HIV-1 takes advantage of the cytoskeleton during replication and cell-to-cell transmission. Viruses. 2011; 3(9):1757-1776. DOI: 10.3390/v3091757 [PubMed: 21994805]

Machtaler S, Choi K, Dang-Lawson M, Falk L, Pournia F, Naus CC, Matsuuchi L. The role of the gap junction protein connexin43 in B lymphocyte motility and migration. FEBS Lett. 2014; 588(8): 1249-1258. DOI: 10.1016/j.febslet.2014.01.027 [PubMed: 24486015]

Majoul I, Shirao T, Sekino Y, Duden R. Many faces of drebrin: from building dendritic spines and stabilizing gap junctions to shaping neurite-like cell processes. Histochem Cell Biol. 2007; 127(4): 355-361. DOI: 10.1007/s00418-007-0273-y [PubMed: 17285341]

Mercer JC, Qi Q, Mottram LF, Law M, Bruce D, Iyer A, Morales JL, Yamazaki H, Shirao T, Peterson $\mathrm{BR}$, August A. Chemico-genetic identification of drebrin as a regulator of calcium responses. Int $\mathrm{J}$ Biochem Cell Biol. 2010; 42(2):337-345. DOI: 10.1016/j.biocel.2009.11.019 [PubMed: 19948240]

Mittelbrunn M, Molina A, Escribese MM, Yanez-Mo M, Escudero E, Ursa A, Tejedor R, Mampaso F, Sanchez-Madrid F. VLA-4 integrin concentrates at the peripheral supramolecular activation complex of the immune synapse and drives T helper 1 responses. Proc Natl Acad Sci U S A. 2004; 101(30):11058-11063. DOI: 10.1073/pnas.0307927101 [PubMed: 15263094]

Mocsai A. Diverse novel functions of neutrophils in immunity, inflammation, and beyond. J Exp Med. 2013; 210(7):1283-1299. DOI: 10.1084/jem.20122220 [PubMed: 23825232]

Monks CR, Freiberg BA, Kupfer H, Sciaky N, Kupfer A. Three-dimensional segregation of supramolecular activation clusters in T cells. Nature. 1998; 395(6697):82-86. DOI: 10.1038/25764 [PubMed: 9738502] 
Naif HM. Pathogenesis of HIV Infection. Infect Dis Rep. 2013; 5(Suppl 1):e6.doi: 10.4081/idr. 2013.s1.e6

Nolz JC, Medeiros RB, Mitchell JS, Zhu P, Freedman BD, Shimizu Y, Billadeau DD. WAVE2 regulates high-affinity integrin binding by recruiting vinculin and talin to the immunological synapse. Mol Cell Biol. 2007; 27(17):5986-6000. DOI: 10.1128/MCB.00136-07 [PubMed: 17591693]

Onabajo OO, Seeley MK, Kale A, Qualmann B, Kessels M, Han J, Tan TH, Song W. Actin-binding protein 1 regulates $\mathrm{B}$ cell receptor-mediated antigen processing and presentation in response to B cell receptor activation. J Immunol. 2008; 180(10):6685-6695. [PubMed: 18453588]

Peitsch WK, Grund C, Kuhn C, Schnolzer M, Spring H, Schmelz M, Franke WW. Drebrin is a widespread actin-associating protein enriched at junctional plaques, defining a specific microfilament anchorage system in polar epithelial cells. Eur J Cell Biol. 1999; 78(11):767-778. DOI: 10.1016/S0171-9335(99)80027-2 [PubMed: 10604653]

Peitsch WK, Hofmann I, Pratzel S, Grund C, Kuhn C, Moll I, Langbein L, Franke WW. Drebrin particles: components in the ensemble of proteins regulating actin dynamics of lamellipodia and filopodia. Eur J Cell Biol. 2001; 80(9):567-579. DOI: 10.1078/0171-9335-00194 [PubMed: 11675932]

Perez-Martinez M, Gordon-Alonso M, Cabrero JR, Barrero-Villar M, Rey M, Mittelbrunn M, Lamana A, Morlino G, Calabia C, Yamazaki H, Shirao T, et al. F-actin-binding protein drebrin regulates CXCR4 recruitment to the immune synapse. J Cell Sci. 2010; 123(Pt 7):1160-1170. DOI: 10.1242/jcs.064238 [PubMed: 20215400]

Permanyer M, Ballana E, Este JA. Endocytosis of HIV: anything goes. Trends Microbiol. 2010; 18(12):543-551. DOI: 10.1016/j.tim.2010.09.003 [PubMed: 20965729]

Permanyer M, Pauls E, Badia R, Este JA, Ballana E. The Cortical Actin Determines Different Susceptibility of Naive and Memory CD4+ T Cells to HIV-1 Cell-to-Cell Transmission and Infection. PLoS One. 2013; 8(11):e79221.doi: 10.1371/journal.pone.0079221 [PubMed: 24244453]

Piguet V, Sattentau Q. Dangerous liaisons at the virological synapse. J Clin Invest. 2004; 114(5):605610. DOI: 10.1172/JCI22812 [PubMed: 15343375]

Ritter AT, Angus KL, Griffiths GM. The role of the cytoskeleton at the immunological synapse. Immunol Rev. 2013; 256(1):107-117. DOI: 10.1111/imr.12117 [PubMed: 24117816]

Rocha-Perugini V, Gonzalez-Granado JM, Tejera E, Lopez-Martin S, Yanez-Mo M, Sanchez-Madrid F. Tetraspanins CD9 and CD151 at the immune synapse support T-cell integrin signaling. Eur J Immunol. 2014a; doi: 10.1002/eji.201344235

Rocha-Perugini V, Gordon-Alonso M, Sanchez-Madrid F. PIP: choreographer of actin-adaptor proteins in the HIV-1 dance. Trends Microbiol. 2014b; 22(7):379-388. DOI: 10.1016/j.tim.2014.03.009 [PubMed: 24768560]

Rossi D, Zlotnik A. The biology of chemokines and their receptors. Annu Rev Immunol. 2000; 18:217-242. DOI: 10.1146/annurev.immunol.18.1.217 [PubMed: 10837058]

Sagar M. Origin of the transmitted virus in HIV infection: infected cells versus cell-free virus. J Infect Dis. 2014; 210(Suppl 3):S667-673. DOI: 10.1093/infdis/jiu369 [PubMed: 25414422]

Schymeinsky J, Gerstl R, Mannigel I, Niedung K, Frommhold D, Panthel K, Heesemann J, Sixt M, Quast T, Kolanus W, Mocsai A, et al. A fundamental role of mAbp1 in neutrophils: impact on beta(2) integrin-mediated phagocytosis and adhesion in vivo. Blood. 2009; 114(19):4209-4220. DOI: 10.1182/blood-2009-02-206169 [PubMed: 19638624]

Schymeinsky J, Sperandio M, Walzog B. The mammalian actin-binding protein 1 (mAbp1): a novel molecular player in leukocyte biology. Trends Cell Biol. 2011; 21(4):247-255. DOI: 10.1016/j.tcb. 2010.12.001 [PubMed: 21232959]

Seeley-Fallen MK, Liu LJ, Shapiro MR, Onabajo OO, Palaniyandi S, Zhu X, Tan TH, Upadhyaya A, Song W. Actin-binding protein 1 links B-cell antigen receptors to negative signaling pathways. Proc Natl Acad Sci U S A. 2014; 111(27):9881-9886. DOI: 10.1073/pnas.1321971111 [PubMed: 24958882]

Sekino Y, Kojima N, Shirao T. Role of actin cytoskeleton in dendritic spine morphogenesis. Neurochem Int. 2007; 51(2-4):92-104. DOI: 10.1016/j.neuint.2007.04.029 [PubMed: 17590478] 
Shirao T, Obata K. Two acidic proteins associated with brain development in chick embryo. J Neurochem. 1985; 44(4):1210-1216. [PubMed: 3973611]

Shurtleff SA, Buijs A, Behm FG, Rubnitz JE, Raimondi SC, Hancock ML, Chan GC, Pui CH, Grosveld G, Downing JR. TEL/AML1 fusion resulting from a cryptic $\mathrm{t}(12 ; 21)$ is the most common genetic lesion in pediatric ALL and defines a subgroup of patients with an excellent prognosis. Leukemia. 1995; 9(12):1985-1989. [PubMed: 8609706]

Skelton TS, Tejpal N, Gong Y, Kloc M, Ghobrial RM. Downregulation of RhoA and changes in T cell cytoskeleton correlate with the abrogation of allograft rejection. Transpl Immunol. 2010; 23(4): 185-193. DOI: 10.1016/j.trim.2010.06.009 [PubMed: 20619345]

Vasiliver-Shamis G, Cho MW, Hioe CE, Dustin ML. Human immunodeficiency virus type 1 envelope gp120-induced partial T-cell receptor signaling creates an F-actin-depleted zone in the virological synapse. J Virol. 2009; 83(21):11341-11355. DOI: 10.1128/JVI.01440-09 [PubMed: 19710135]

Vaskova M, Kovac M, Volna P, Angelisova P, Mejstrikova E, Zuna J, Brdicka T, Hrusak O. High expression of cytoskeletal protein drebrin in TEL/AML1pos B-cell precursor acute lymphoblastic leukemia identified by a novel monoclonal antibody. Leuk Res. 2011; 35(8):1111-1113. DOI: 10.1016/j.leukres.2011.03.028 [PubMed: 21497902]

Vicente-Manzanares M, Sanchez-Madrid F. Role of the cytoskeleton during leukocyte responses. Nat Rev Immunol. 2004; 4(2):110-122. [PubMed: 15040584]

Vorster PJ, Guo J, Yoder A, Wang W, Zheng Y, Xu X, Yu D, Spear M, Wu Y. LIM kinase 1 modulates cortical actin and CXCR4 cycling and is activated by HIV-1 to initiate viral infection. J Biol Chem. 2011; 286(14):12554-12564. DOI: 10.1074/jbc.M110.182238 [PubMed: 21321123]

Wang X, Bjorklund S, Wasik AM, Grandien A, Andersson P, Kimby E, Dahlman-Wright K, Zhao C, Christensson B, Sander B. Gene expression profiling and chromatin immunoprecipitation identify DBN1, SETMAR and HIG2 as direct targets of SOX11 in mantle cell lymphoma. PLoS One. 2010; 5(11):e14085.doi: 10.1371/journal.pone.0014085 [PubMed: 21124928]

Willeke T, Schymeinsky J, Prange P, Zahler S, Walzog B. A role for Syk-kinase in the control of the binding cycle of the beta2 integrins (CD11/CD18) in human polymorphonuclear neutrophils. J Leukoc Biol. 2003; 74(2):260-269. [PubMed: 12885943]

Yamazaki H, Takahashi H, Aoki T, Shirao T. Molecular cloning and dendritic localization of rat SH3P7. Eur J Neurosci. 2001; 14(6):998-1008. [PubMed: 11595038]

Yeoh EJ, Ross ME, Shurtleff SA, Williams WK, Patel D, Mahfouz R, Behm FG, Raimondi SC, Relling MV, Patel A, Cheng C, et al. Classification, subtype discovery, and prediction of outcome in pediatric acute lymphoblastic leukemia by gene expression profiling. Cancer Cell. 2002; 1(2): 133-143. [PubMed: 12086872]

Yoder A, Yu D, Dong L, Iyer SR, Xu X, Kelly J, Liu J, Wang W, Vorster PJ, Agulto L, Stephany DA, et al. HIV envelope-CXCR4 signaling activates cofilin to overcome cortical actin restriction in resting CD4 T cells. Cell. 2008; 134(5):782-792. DOI: 10.1016/j.cell.2008.06.036 [PubMed: 18775311]

Yuan M, Mogemark L, Fallman M. Fyn binding protein, Fyb, interacts with mammalian actin binding protein, mAbp1. FEBS Lett. 2005; 579(11):2339-2347. DOI: 10.1016/j.febslet.2005.03.031 [PubMed: 15848169]

Yuseff MI, Lennon-Dumenil AM. B Cells use Conserved Polarity Cues to Regulate Their Antigen Processing and Presentation Functions. Front Immunol. 2015; 6:251.doi: 10.3389/fimmu. 2015.00251 [PubMed: 26074919]

Zhong P, Agosto LM, Munro JB, Mothes W. Cell-to-cell transmission of viruses. Curr Opin Virol. 2013; 3(1):44-50. DOI: 10.1016/j.coviro.2012.11.004 [PubMed: 23219376] 

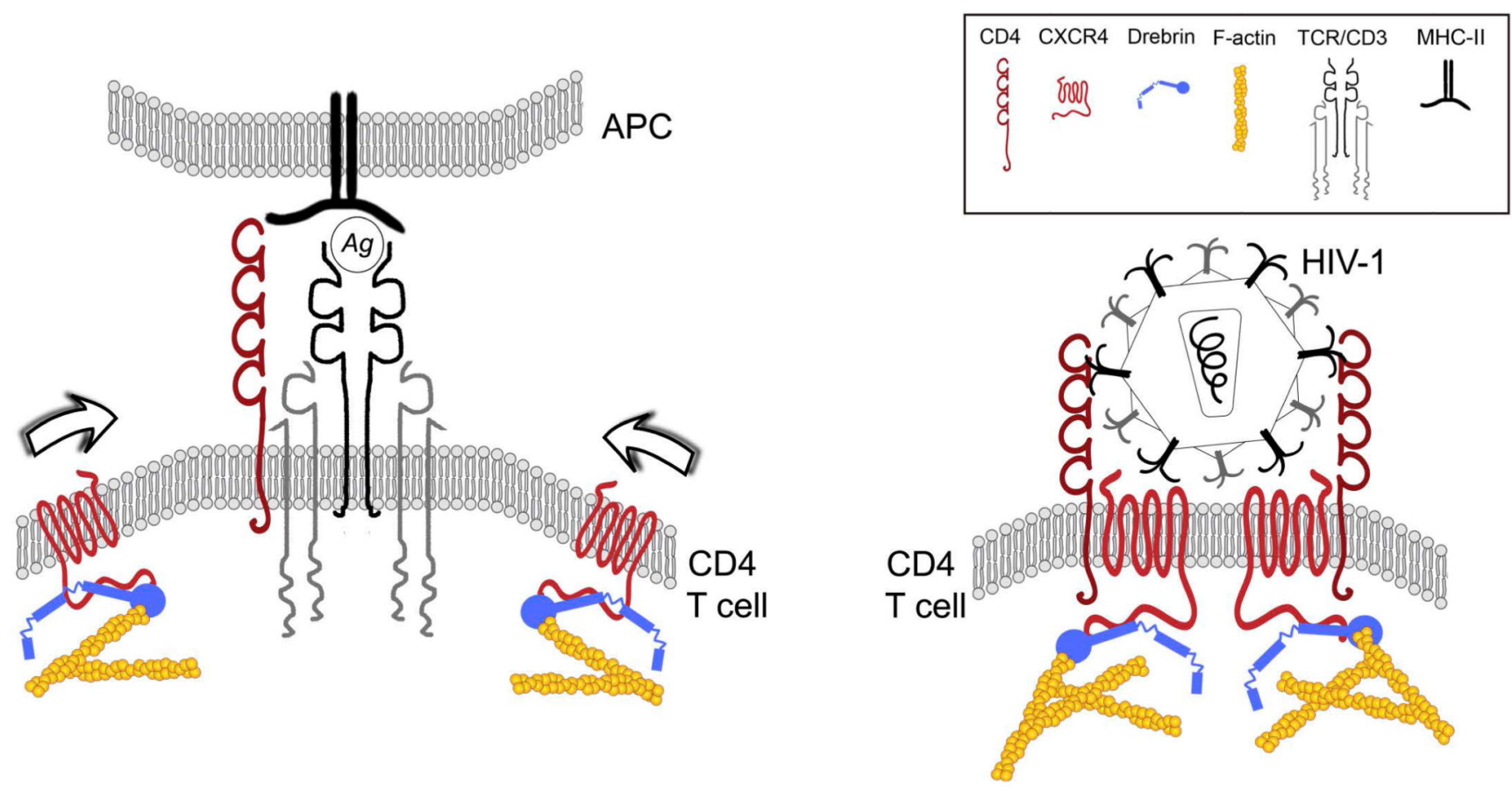

Figure 1. Role of drebrin during $\mathrm{CD4}^{+} \mathrm{T}$ cell activation and HIV-1 infection.

Left panel: $\mathrm{CD}^{+} \mathrm{T}$ cells recognize an antigenic peptide $(\mathrm{Ag})$ loaded in the MHC-II of an antigen presenting cell (APC), and organizes its molecules forming the immunological synapse (IS). Drebrin is recruited to the periphery of the IS together with F-actin, and is responsible for the accumulation of CXCR4 in this area. Right panel: HIV-1 binds to CD4 and $\mathrm{CXCR} 4$ on the surface of $\mathrm{CD}^{+}{ }^{+} \mathrm{T}$ cells, promoting protein rearrangements that generate the virological synapse (VS), similar to the IS. Drebrin is recruited to the VS and participates in the regulation of local actin polymerization. Proteins and structures depicted are not to scale. 